\title{
Recepção e influência de Lorenzo Perosi (1872-1956) na música religiosa de Alberto Nepomuceno (1864-1920)
}

\author{
Thiago Plaça Teixeira \\ Universidade Estadual do Paraná \\ thiagoplacateixeira@gmail.com
}

Resumo: O presente artigo visa analisar a possível influência musical do compositor italiano Lorenzo Perosi (1872-1956) na música sacra e religiosa do brasileiro Alberto Nepomuceno (1864-1920). Após contextualizar a recepção da música de Perosi no Brasil entre o final do século XIX e as primeiras décadas do século XX, apresenta-se uma análise de diferentes aspectos musicais de obras de Nepomuceno que evidenciam uma influência direta de Perosi, via intertextualidade musical, ou uma comum referência estilística para ambos os compositores. Verificou-se este último tipo de influência no tratamento dado à harmonização do canto gregoriano e no uso de tópicas e elementos representativos em obras instrumentais e corais de Nepomuceno; e a intertextualidade musical na sua Missa a duas vozes, sobretudo no Sanctus.

Palavras-chave: Música sacra. Lorenzo Perosi. Alberto Nepomuceno.

\section{Reception and Influence of Lorenzo Perosi In Alberto Nepomuceno's Religious Music}

Abstract: This article aims to analyze the possible musical influence of Italian composer Lorenzo Perosi in the Alberto Nepomuceno's sacred and religious music. After placing the general context of the reception of Perosi music in Brazil between the end of the 19th century and the first decades of the 20th century, is presented an analysis of different musical features in Nepomuceno's works that evidence a direct influence of Perosi, via musical intertextuality, or a common stylistic reference for both composers. It was found the latter influence in the treatment of plainchant harmonization and in the use of topics and representative qualities in Nepomuceno's instrumental and choral works; and the musical intertextuality was found in his Mass for two voices, especially in its Sanctus.

Keywords: Sacred music. Lorenzo Perosi. Alberto Nepomuceno.

\section{A música de Perosi no Brasil}

Nosso Imperador Dom Pedro II (1825-1891) visitou certa vez, por ocasião de uma de suas viagens à Itália, a Catedral de Tortona, pequena cidade da região do Piemonte. Assim que adentrou o edifício religioso, impressionou-se com o som do órgão que lá ressoava e, juntamente com sua comitiva, dirigiu-se ao coro, onde verificou que o habilidoso organista em questão era um rapaz de apenas quinze anos. Estupefato, o monarca entrega ao jovem uma moeda brasileira com sua própria efígie gravada e diz: “Tome. Quero lhe dar meu retrato.” Em seguida pergunta pelo nome do músico e recebe como resposta: Renzo (CIAMPA, 2006, p. 47). 
O talentoso organista em questão era Lorenzo Perosi, apelidado de Renzo, nascido na mesma Tortona a 21 de dezembro de 1872 e falecido em Roma, a 12 de outubro de 1956. Iniciou seus estudos musicais com seu pai, Giuseppe Perosi (1849-1908), que era Maestro di Cappela da Catedral de Tortona e proeminente músico de igreja. Estudou depois com o respeitado professor Michele Saladino (1835-1912) no Conservatório de Milão, onde diplomou-se em 1892. Já em 1890, com apenas 18 anos, obteve seu primeiro cargo profissional como organista e professor de música na Abadia de Montecassino, na França. Após seus estudos em Milão, passou um ano de estudo na Kirchenmusikschule, em Regensburg, na Alemanha, com Franz Xaver Haberl (1840-1910), músico e musicólogo, pioneiro editor das obras de Palestrina (1525-1594) e Lassus (1532-1594). Em seguida, assumiu o trabalho de professor e diretor de música sacra em Imola, na Itália, entre 1892 e 1894, ano em que visitou a famosa Abadia de Solesmes, na França, onde estudou canto gregoriano com Dom André Mocquereau (1849-1930) e Dom Joseph Pothier (1835-1923), importantes nomes do processo de restauração do cantochão tradicional. Entre 1894 e 1907, Perosi assumiu o importante cargo de Maestro da Capella Marciana na Basílica de São Marcos em Veneza, cujo então Patriarca era Dom Giuseppe Sarto (1835-1914), futuro Papa São Pio $X^{1}$, com quem cultivou grande amizade e por quem foi ordenado sacerdote em 1895. Em 1898, Perosi foi indicado para o posto de Maestro Perpetuo della Capela Sistina, isto é, diretor do coro da Capela Sistina no Vaticano, cargo que manteve, ainda que com algumas interrupções, até sua morte, em 1956 (CIAMPA, 2006; WATERHOUSE, 2001).

Como compositor, o período de maior produtividade de Perosi foi entre 1894 a 1907. Particularmente famoso por seus Oratórios ${ }^{2}$, que alcançaram enorme popularidade na Europa, Perosi também compôs várias Missas e obras sacras menores, além de música secular, como, por exemplo, concertos e peças para música de câmara.

Entre o final do século XIX e o início do século XX vários periódicos brasileiros frequentemente publicaram notícias sobre a repercussão da obra de Perosi na crítica musical europeia da época. Na célebre coluna Theatros e música do Jornal do Commercio

\footnotetext{
${ }^{1}$ Em 1903, o Cardeal Sarto foi eleito Papa e uma de suas primeiras ações como Sumo Pontífice foi o documento sob a forma de Motu próprio, Tra le sollecitudini, regulamentando a música sacra nas igrejas católicas.

${ }^{2}$ Segundo Smither, “os quatorze oratórios de Perosi (1872-1956) são as obras italianas mais importantes neste gênero [oratório] entre o final do século XIX e o início do século XX” (2000, p. 621, tradução nossa).
} 
(Rio de Janeiro) lia-se já em 1898 os ecos do fervor com que os oratórios de Perosi eram recebidos no meio musical italiano:

No firmamento da arte musical italiana acaba de surgir um novo astro. Esse novo astro anuncia-se na pessoa de um jovem eclesiástico de 25 anos, o Padre Perosi. Os jornais italianos ultimamente recebidos consagram-lhe artigos ditirâmbicos a propósito de um oratório da sua composição, que se intitula Ressurreição de S. Lázaro ${ }^{3}$, e foi sucessivamente executado em Bolonha, Turim, Veneza e Florença. O êxito cresce de dia para dia, e os críticos saúdam já o maestro como o restaurador da música sacra na Itália.

Atraído pelo entusiasmo, que a obra tinha suscitado em outras cidades, um público escolhido e muito numeroso afluiu ao teatro Pagliano em Florença, para ouvir a execução do famoso oratório. A Ressurreição de S. Lázaro produziu uma impressão profunda, e os triunfos já alcançados acentuaramse mais no teatro da cidade das flores.

No dizer dos críticos mais autorizados, o novo oratório reveste uma forma de arte, uma inspiração, um sentimento, que colocam o autor ombro a ombro com os grandes mestres do gênero: Palestrina, Haendel, Bach, Haydn. O sentimento religioso, aliado a uma genial inspiração auxiliada por sólidos estudos, fez reviver um ramo da arte musical que se podia já considerar morto (JORNAL DO COMMERCIOa, 1898, grifo nosso).

Também no Rio de Janeiro pôde-se ouvir o mencionado Oratório A ressurreição de

\section{Lázaro de Perosi em 1906 no Teatro São Pedro:}

Por iniciativa do monsenhor Lopes, vigário da freguesia e Sant'Anna, brevemente será evado (sic), pela primeira vez nesta capital, no teatro $S$. Pedro, o grande Oratório a Ressurreição de Lázaro do maestro Perosi. A execução do trabalho do laureado maestro, será feita em benefício das obras da Catedral e altar-mor da matriz de Sant'Anna, tomando parte os primeiros artistas da Companhia Lírica Italiana e os professores da Schola Cantorum Sancte Caeciliae. A orquestra será composta de 60 professores e a massa coral de 120 cantores de ambos os sexos. A direção será confiada ao maestro cavalheiro Oscar Anselmi, que, com sucesso, dirigiu o Oratório em Verona, em presença do maestro Perosi. Atenta a reconhecida competência do maestro Anselmi, deve esperar-se completo êxito. É bem possível que sua eminência o cardeal honre com sua presença a grande execução do Oratório" (CORREIO DA MANHÃ, 1906).

Entretanto, a presença musical de Perosi no Brasil no início do século XX é mais fortemente verificada no âmbito específico da música litúrgica, mais do que propriamente no âmbito dos oratórios. Com efeito, nota-se nos programas musicais das solenidades religiosas católicas deste período na capital brasileira a execução de diversas obras

\footnotetext{
${ }^{3} \mathrm{O}$ mesmo Jornal do Commercio noticiaria no ano seguinte a nomeação de Perosi como diretor musical da Capela Sistina. Além disso, apresentava aos leitores a programação do Teatro Scala de Milão. Observa-se que, ao lado das tradicionais óperas, também seria executado o Oratório Ressurreição de Lázaro, de Perosi: "O teatro Scala de Milão publicou seu programa para a estação de carnaval e quaresma, que deveria abrirse a 26 de Dezembro último. O repertório compreende Falstaff, Os Mestres Cantores de Nuremberg, O Rei de Lahore, Iris, Norma, Huguenotes e mais dois bailados: o Carrilhão, de Massenet, e Rosa d'Amor de Joseph Bayer. [...] Às obras dramáticas acima indicadas temos de acrescentar as três composições religiosas de Verdi: Stabat Mater, Laudi ala Vergine, Te Deum e o oratório do Abade Perosi a Ressurreição de Lázaro. "O Abade D. Lourenço Perosi foi nomeado pelo Papa Diretor dos cantores da Capela Sixtina" (JORNAL DO COMMERCIO, 1899, grifo nosso).
} 
litúrgicas de Perosi. Sabe-se, por exemplo, que a Schola cantorum Santa Cecília, coro da Igreja de Sant'Ana (Rio de Janeiro) dirigido pelo Pe. José Alpheu Lopes de Araújo ${ }^{4}$, em diversas cerimônias litúrgicas executou alguma obra de Perosi. Por ocasião da morte do Papa São Pio X em 1914, por exemplo, as exéquias que foram celebradas na Catedral do Rio de Janeiro, com presença inclusive de importantes autoridades civis, tiveram como música o Requiem de Perosi: ${ }^{5}$

Realizaram-se ontem, na Catedral Metropolitana, as solenes exéquias que o Cabido desta cidade mandou celebrar por alma de Sua Santidade o Papa Pio X. Desde cedo, nas proximidades da igreja aglomerava-se o povo, contido por um cordão de isolamento. Mais tarde vieram também alinharse ao longo da rua 7 de Setembro o piquete de cavalaria que escoltou o Sr. Presidente da República e um regimento do Exército, que prestou as honras militares. [...]

No interior, o templo apresentava uma imponência austera: as profundas luzes dos candelabros pendentes ressaltavam sobre o veludo negro que forrava os altares. [...] A nave enchia-a o povo apinhado. $\mathrm{Na}$ primeira tribuna, junto ao Evangelho, viam-se o Sr. Presidente da República, a Sra. Hermes da Fonseca e os Srs. Barões de Teffé; na segunda as casas civil e militar da presidência; ocupavam a terceira e a quarta os Srs. Ministros e suas senhoras." [...]

Antes de começar a missa pontifical, a orquestra, grande coral, executou o "Adagio trio", de Callegari. E iniciou-se a cerimônia: subiu ao altar o Sr. Bispo D. Sebastião Leme ... E, ao longo da missa, ao Introito, ao Kyrie, Gradual, Tractus, Dies Irae, Sanctus e Agnus, a grande coral, organizada pelo zelo infatigável de Monsenhor Alpheu Lopes e regida por ele próprio, fazia ouvir os trechos correspondentes da "Missa de Requiem", de Perosi, uma admirável página de música, escrita em estilo clássico, muito polifônico e dramático, cheio de modulações logicamente concatenadas, e de uma harmonização riquíssima e surpreendente. (JORNAL DO COMMERCIO, 1914b, grifo nosso).

Outras Missas de Perosi foram também frequentemente executadas pelo mesmo coro do Pe. Alpheu no Rio de Janeiro, tais como a Missa [Prima] Pontificalis (1897) ${ }^{6}$, a

\footnotetext{
4 “O Pe. José Alpheu Lopes de Araújo, cónego da Catedral Metropolitana, Mestre de Capela do Cabido e (1924) professor de órgão e harmónio do Instituto Nacional de Música, ordenado em 1894 no Colégio Pio Latino em Roma, organizou, logo que voltou ao Brasil, um notável coro de meninos na Matriz de Santana, dando um exemplo prático de música sacra correta." (SCHUBERT, 1980. p. 22).

${ }^{5}$ No ano seguinte, noticia-se também o Requiem de Perosi sendo executado na Catedral por ocasião do falecimento do Imperador austríaco Francisco José: "Realizaram-se ontem na Catedral Metropolitana as exéquias em sufrágio da alma de S. M. o Imperador Francisco José. [...]A "Schola Cantorum Santae Ceciliae" executou a missa de "Requiem", de Perosi." (JORNAL DO COMMERCIO, 1916c).

6 "Revestiu-se ontem do máximo esplendor a festa de São Miguel Arcanjo, nesta matriz [Sant'Ana], promovida pela Venerável Irmandade. [...] A parte vocal e instrumental esteve entregue à Schola Cantorum de Santa Cecília, sob a regência do diretor, cônego Alpheu Lopes de Araújo, que fez executar o seguinte programa: "Missa Pontificalis", de Perosi [...]." (JORNAL DO COMMERCIO, 1915).
} 
Missa Secunda Pontificalis (1906) ${ }^{7}$, a Missa Davidica (1894) ${ }^{8}$, a Missa Eucharistica $(1897)^{9}$ e a Missa Benedicamus Domino $(1899)^{10}$. Na edição de 31 de agosto de 1904 do Jornal do Brasil, lê-se ainda uma série de notícias sobre um importante evento para os católicos brasileiros, uma grande peregrinação ao Santuário de Aparecida, promovida para comemorar o quinquagésimo aniversário da definição do dogma da Imaculada Conceição de Nossa Senhora. Fizeram-se presentes em Aparecida diversos Bispos de todo o Brasil, merecendo destaque a participação do Cardeal Dom Joaquim Arcoverde de Albuquerque Cavalcanti, Arcebispo do Rio de Janeiro, a quem coube a celebração da Missa Pontifical no dia 8 de setembro, data destinada às cerimônias de solene Coroação de Nossa Senhora e ocasião em que se noticiava a execução da Missa Te Deum laudamus de Perosi (JORNAL DO BRASIL, 1904).

A ampla divulgação da música de Lorenzo Perosi no meio eclesiástico e seu prestígio junto à crítica musical parecem tê-lo alçado também no Brasil ao posto de referência em questão de música sacra católica na primeira metade do século XX. Até mesmo Heitor Villa-Lobos (1887-1959), reconhecidamente zeloso de sua pretensa originalidade artística, teria reconhecido Perosi como modelo a ser seguido, conforme expõe o escritor Manuel Bandeira (1886-1968) em um de seus textos do Jornal do Brasil:

Havia muito tempo que eu não tinha o prazer de abraçar o nosso grande Villa, que é como costumamos chamar, os seus íntimos, Heitor VillaLobos. Sabendo que ele estava de volta à terrinha, fui logo procurá-lo no seu apartamento da Rua Araújo Porto Alegre. Encontrei-o como ele é sempre encontrado a qualquer hora do dia ou da noite: trabalhando. Desta vez estava trabalhando no Magnificat que lhe foi encomendado pelo Vaticano. - Então, bichão, agora na música sacra? - Agora? Você se esquece que eu já escrevi quatro missas, uma de Requiem, que tenho dois volumes de motetos, e muitas outras coisas avulsas. Fiquei encabulado. Mas quem já deu a volta do Villa? No outro dia Mariuccia Jacovino disse-

\footnotetext{
7 “A Mesa Administrativa desta Venerável Irmandade [do Príncipe dos Apóstolos S. Pedro] celebrará no corrente ano, com o maior brilhantismo, a festa do Santo Patriarca, pela forma seguinte: [...] A parte musical será confiada à Schola Cantorum Santae Ceciliae, que, sob a regência do Revmo. Cônego Alpheu Lopes de Araújo, executará o seguinte programa: [...] Missa secunda pontificalis, de Perosi, para contraltos, tenores e baixos (executada pela primeira vez)." (JORNAL DO COMMERCIO, 1916a).

8 "Teve toda a pompa a festa que em louvor ao seu glorioso orago, fez celebrar ontem a Irmandade de S. Miguel e Almas, da matriz de Santa Rita. [...] No coro da igreja, uma orquestra sob a direção do maestro Sr. Luiz Pedroza, executou o seguinte programa sacro: [...] a religiosa "Messe Davidica", do compositor sacro Don Lorenzo Perosi [...].” (JORNAL DO COMMERCIO, 1916b).

9 “A Mesa Administrativa desta Venerável Irmandade [do Príncipe dos Apóstolos S. Pedro] celebra no corrente ano, a festa do Santo Patriarca, seu padroeiro, pela forma seguinte [...] A parte musical será confiada à "Schola Cantorum Santae Ceciliae", que executará o seguinte programa: [...]"Missa Eucharistica" a 4 vozes desiguais, de Perosi [...] "Cantabo Domino", de Perosi." (JORNAL DO COMMERCIO, 1914a).

10 “'O Apostolado do Coração da Matriz de Sant'Anna realizou ontem a festa do Sagrado Coração de Jesus, com missa pontifical às 10 horas [...] A Escola Cantorum Santa Cecilia, sob a regência do Padre Alpheu Lopes de Araújo, executou a missa denominada Benedicamus Domino, do Abade Perosi." (JORNAL DO COMMERCIO, 1910).
} 
me que o Quarteto do Rio de Janeiro estava ensaiando o $16^{\circ}$ quarteto do Villa. O último de que eu tinha notícia era o oitavo. E me lembrava da conversa que a propósito dele tivera com o compositor. - A verdadeira sonoridade do quarteto é a de Haydn, dissera-me Villa. Beethoven é demasiado egocêntrico: é ele, ele e mais nada. Beethoven, sinfonia; Haydn, quarteto. E na música sacra quem é que é? Perguntei agora, que ouvia falar do Magnificat para o Vaticano. Villa sorriu: - Perosi! Mas eu: - E Palestrina? - Palestrina, Vitoria são muito rigorosos, muito rígidos. Sabes que eu sou pecador: tenho pecado muito! (JORNAL DO BRASIL, 1958, grifo nosso).

\section{A música sacra e religiosa de Nepomuceno}

Do mencionado período entre o final do século XIX e as primeiras décadas do século XX é Alberto Nepomuceno considerado comumente como grande expoente da música brasileira, seja pela sua intensa atividade musical como regente e compositor, seja também pelo seu trabalho à frente do Instituto Nacional de Música. Sabe-se também que foi ele diretamente interessado e atuante na questão da regulamentação da música sacra católica no Rio de Janeiro. E o seu contato com a música litúrgica verifica-se também na sua formação musical recebida na Europa, sobretudo na Schola Cantorum em Paris, no seu trabalho em prol da recuperação da obra do Pe. José Maurício Nunes Garcia (17671830) e nas suas próprias composições sacras e religiosas (cf. GOLDBERG, 2006).

O repertório sacro/religioso produzido por Alberto Nepomuceno pode ser classificado em três categorias distintas: 1) música instrumental religiosa; 2) oratório em sentido lato; e 3) música sacra ${ }^{11}$. À primeira categoria pertence as peças Offertoire (órgão, 1912) e Cloches de Noël ["Sinos de Natal"] (piano, 1915). À segunda categoria pertencem as peças Ave Maria [texto de X. Silveira Jr.] (canto e piano, 1887), Ave Maria [texto de J. Galeno] (coro feminino, 1897), Ingemisco (canto e piano, 1899), Em Bethleem (canto, coro e orquestra, 1903), Canto nupcial (canto e piano, 1907) e Invocação à Cruz (coro e piano, s.d.). À terceira categoria pertencem as peças Canto fúnebre (coro, 1896), $O$ salutaris hostia (canto e órgão, 1897), Panis angelicus (duas vozes e órgão, 1909), Ecce panis angelorum (duas vozes e órgão, 1911), O salutaris hostia (coro feminino, 1911), Tantum ergo (coro e órgão, 1911), Missa a duas vozes (coro e órgão, 1915) e Ave Maria (canto e órgão, s.d.) (TEIXEIRA, 2019).

\footnotetext{
${ }^{11}$ Considera-se aqui como música sacra aquela música destinada a "revestir de adequadas melodias o texto litúrgico" no culto público da Igreja Católica Apostólica Romana (Documentos sobre a música litúrgica, 2005, p. 15).
} 
Considerando, pois, a relevância de Alberto Nepomuceno no cenário da música erudita brasileira e, ao mesmo tempo, a sua inserção em um contexto histórico em que a música sacra católica recebe intensa atenção por parte das autoridades eclesiásticas e em que Lorenzo Perosi assume a posição de referência em tal gênero musical, propomo-nos no presente artigo investigar a possível influência musical do compositor italiano nas obras religiosas de Alberto Nepomuceno.

Para tanto, dividimos a abordagem em duas partes. Primeiramente, trataremos de alguns aspectos musicais comuns a Perosi e a Nepomuceno, mas que não necessariamente são exclusivos do compositor italiano. Em segundo lugar, trataremos de casos concretos de intertextualidade musical, apontando-se para influência direta de obras específicas de Perosi na produção religiosa de Nepomuceno.

\section{O canto gregoriano e o oratório}

Na obra sacra de Lorenzo Perosi, pode-se encontrar um tipo de harmonização de cantos gregorianos bastante corrente no final do século XIX. Trata-se basicamente de um procedimento em que a cada nota do cantochão corresponde ao órgão um acorde com notas pertencentes ao modo da peça gregoriana, preferencialmente em estado fundamental. É, em suma, o que é proposto no Traité théorique et pratique de l'accompagnement du plain-chant de Louis Niedermeyer e Joseph d'Ortigue, publicado em 1856. ${ }^{12} \mathrm{Na}$ Missa De Beata, por exemplo, que, além de algumas peças originais para órgão, consiste basicamente em uma versão harmonizada de uma Missa completa gregoriana (Ordinário extraído da Missa IX gregoriana e o Próprio da Missa do Dia de Natal), Perosi apresenta a mesma concepção para a harmonização do cantochão: acordes consonantes, um para cada nota da melodia, e ausência de dissonâncias (Fig. 1).

\footnotetext{
${ }^{12}$ Esse tratado apresenta algumas poucas regras fundamentais para o acompanhamento do cantochão: 1) usar exclusivamente em cada modo as notas da escala; 2 ) usar frequentemente as tríades da nota final e da dominante de cada modo; 3 ) usar exclusivamente as fórmulas harmônicas próprias às cadências de cada modo; 4) não usar no acompanhamento do cantochão outro acorde senão as tríades consonantes e sua primeira inversão; 5) as leis que governam a melodia gregoriana [p.ex.: uso do Sib] devem ser observadas também em cada uma das quatro vozes do acompanhamento instrumental; 6) sendo a melodia o mais essencial do cantochão, ela deve sempre estar na voz superior do acompanhamento instrumental (NIEDERMEYER; D’ORTIGUE, 1905, p. 14-16).
} 


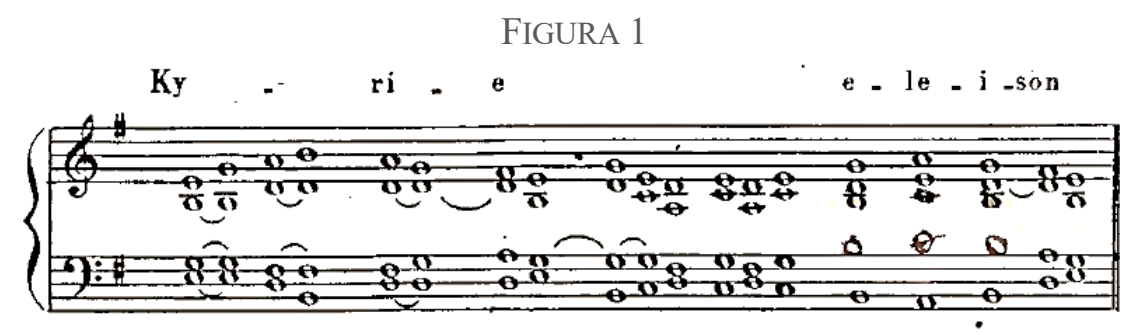

Perosi: exemplo de harmonização do cantochão na Missa De Beata. Fonte: PEROSI (s.d.).

Na obra Cloches de Noël de Nepomuceno encontra-se a mesma técnica de harmonização. Trata-se de uma obra de caráter religioso para piano solo composta em 1915 para um jornal carioca, O Imparcial. Nela o compositor insere a melodia do canto gregoriano Hodie Christus natus est, antífona do Magnificat do Ofício de segundas Vésperas do dia 25 de dezembro (Nascimento do Senhor) na liturgia romana. Facilmente se verifica que Nepomuceno se atém às tríades pertencentes ao modo de Ré do cantochão original (Modo I - Dórico ou Protus) e usa frequentemente os acordes sobre a nota finalis (Ré) e sobre a dominante (Lá) (Fig. 2).

FIGURA 2

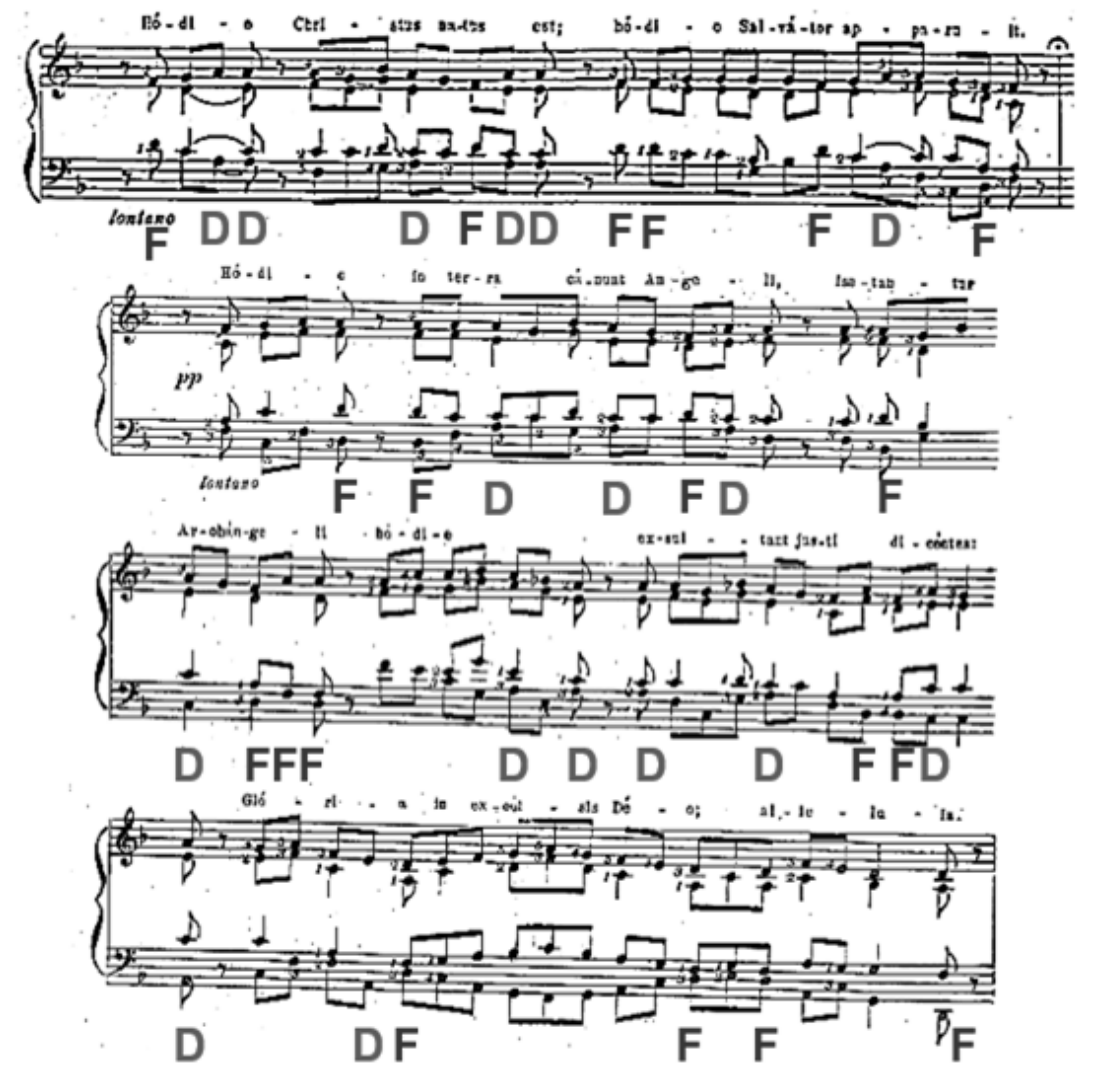

Gregoriano harmonizado em Cloches de Noël-acordes sobre a nota finalis (F) e sobre a dominante (D). Fonte: NEPOMUCENO (s.d.) [1915a]. 
No Catálogo geral das obras de Nepomuceno encontra-se uma única obra classificada como oratório. Trata-se da peça ali intitulada A pastoral, composta em 1902 durante estada do compositor em Petrópolis/RJ, e descrita como "episódio de Natal" e “auto religioso em um prólogo e três atos", com duração de aproximadamente 35 minutos. A estreia da peça é apontada como sendo o dia de Natal (25 de dezembro) do ano de 1903, no Teatro São Carlos, em Campinas/SP, indicando a mesma fonte que a obra completa teve "música composta por Sant'Ana Gomes (Prólogo), Henrique Oswald (Anunciação), Francisco Braga (A Visitação) e Alberto Nepomuceno (Em Belém)” (CORREA, 1996, p. 51).

O libreto utilizado por Nepomuceno para composição de seu "oratório" é o $3^{\circ}$ quadro da obra Pastoral do escritor brasileiro Henrique Maximiano Coelho Netto (18641934). Musicalmente, a composição de Nepomuceno divide-se em seis partes: 1) Prelúdio orquestral; 2) peça para coro a 4 vozes (soprano, contralto, tenor e baixo) a cappella, o "Coro dos emoritas"; 3 ) peça para coro feminino a 4 vozes (soprano 1 e 2 ; contralto 1 e 2), o "Coro dos anjos"; 4) ária para mezzo-soprano e orquestra, a "Cantilena"; 5) peça para coro masculino e orquestra, o "Coro dos pastores", à qual se segue imediatamente um interlúdio orquestral e uma recapitulação do "Coro dos anjos" acompanhado pela orquestra; e 6) peça final para coro e orquestra, com recapitulação de trechos dos coros anteriores. A partitura manuscrita do compositor traz como título Em Bethleem: auto pastoril de Coelho Netto, música de Alb. Nepomuceno, op. 25.

Diferentemente do que é indicado no Catálogo (CORREA, 1996), contudo, onde Em Bethleem é classificada como oratório, a obra é, em verdade, uma música incidental. Com efeito, diferentemente do gênero oratório, em que tradicionalmente não há representação cênica, a peça de Nepomuceno é parte integrante de uma ação teatral, e sua própria integridade enquanto obra não lhe pode ser desvinculada. Mesmo assim, Nepomuceno utiliza alguns procedimentos compositivos comuns à produção musical europeia de oratórios, particularmente nos de temática natalina. Trata-se da tópica pastoril $^{13}$ e de elementos representativos da música angélica.

\footnotetext{
${ }^{13}$ A temática pastoral especificamente em sentido religioso surge naturalmente do próprio fato de que na Sagrada Escritura há diversas referências a ela. No Antigo Testamento tem-se Jacó, Isaac e Abraão descritos como pastores; Saul e Davi como pastores; e, enfim, o próprio Cristo se denomina o Bom Pastor e tem seu nascimento revelado primeiramente aos pastores. A aproximação entre a temática pastoral e a festa específica do Natal se dá também e por algumas tradições musicais, sobretudo italianas, que envolviam os festejos religiosos na época natalina (MONELLE, 2006, p. 198).
} 
Segundo Monelle (2006), os significantes pastorais estão entre os procedimentos mais utilizados pelos compositores ao longo da história da música: os instrumentos característicos, a siciliana e a simplicidade rural. Os instrumentos musicais que imediatamente remetem à temática pastoril são alguns instrumentos de sopro, o que decorre de algumas referências que se têm acerca da música na Antigüidade, particularmente o aulós, a flauta de pã e a gaita de foles, com seu efeito característico: o bordão. No aspecto rítmico, o significante pastoral mais frequente é o compasso composto típico da chamada siciliana, com a métrica pastoral padrão (12/8 ou 6/8) correspondente às execuções dos pastores de Abruzzi que desciam a Roma na época do Natal, sendo a siciliana um eventual refinamento da música dos pifferari, como eram conhecidos esses músicos, que tocavam instrumentos de sopro como a gaita de foles e os pifferi (espécie de oboé). Finalmente, o terceiro significante pastoril seria a simplicidade rural, já que se entende comumente que pessoas do campo se expressam com palavras simples, o que seria concretizado musicalmente em linhas vocais raramente excedendo uma quinta, na melodia desenvolvendo-se por graus conjuntos, na preferência por frases cantantes e melodiosas, no ritmo limitado a padrões constantemente repetidos, na harmonia não expressiva e na preferência pela tonalidade maior (MONELLE, 2006, p. 207-222).

Esses mesmos três significantes pastoris se encontram claramente no Prelúdio de Nepomuceno. Primeiramente pelos solos de oboé e clarinete, pelo uso de tercinas e pelo efeito de bordão no solo de clarinete (Fig. 3). Em segundo lugar, também por algumas características do próprio tema que o compositor apresenta a partir do compasso 14, tema este construído basicamente sobre as notas da tríade da tônica (Fig. 4).

\section{FIGURA 3}
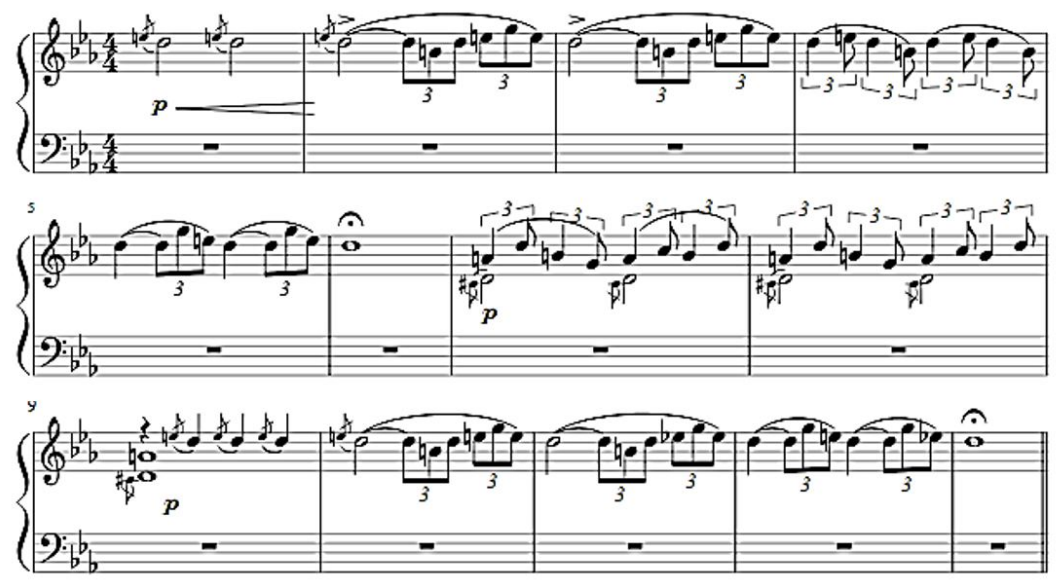

Prelúdio de Em Bethleem de Nepomuceno, c. 1-13. Fonte: O autor (2019). 
FIGURA 4

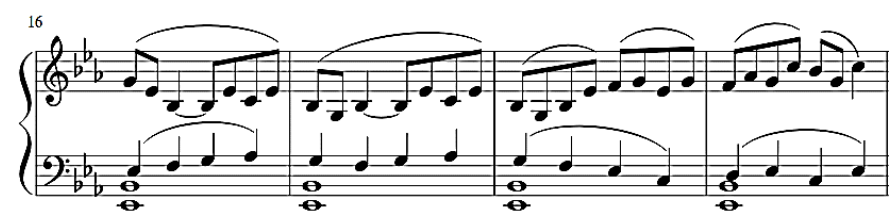

Tema do Prelúdio de Em Bethleem de Nepomuceno. Fonte: O autor (2019).

Na última página do manuscrito de Em Bethleem verifica-se explicitamente que o próprio compositor entendeu conferir este caráter pastoral ao Prelúdio. Encontra-se ali a indicação do que seria o "motivo pastoril" utilizado na obra: uma pequena frase musical para instrumentos de sopros, com apojaturas e tercinas sobre um baixo a modo de bordão com um intervalo de quinta justa (Fig. 5).

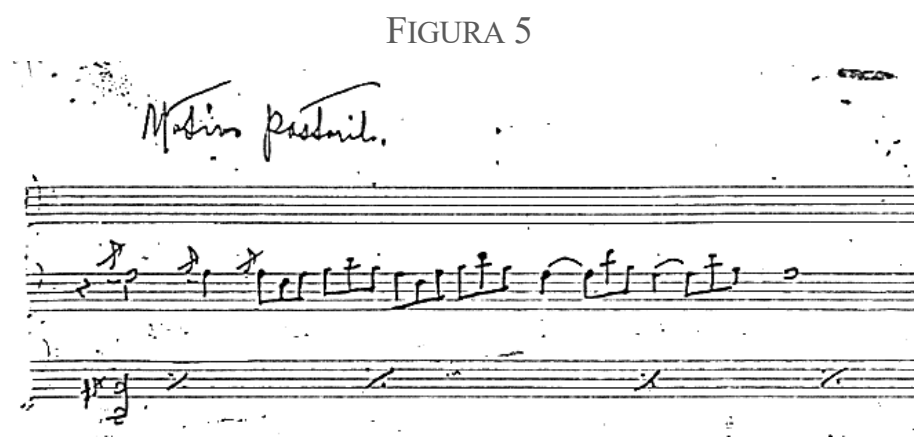

Motivo pastoril no manuscrito de Em Bethleem. Fonte: NEPOMUCENO (s.d.) [1903].

Na peça em que Nepomuceno insere o canto dos anjos por ocasião do anúncio do nascimento de Cristo aos pastores, utiliza-se como texto a frase "Glória a Deus nas alturas e paz na terra aos homens de boa vontade". Musicalmente, o trecho é formado por dois períodos musicais, sendo o primeiro direcionado harmonicamente da tônica para a dominante (c. 1-11) com o texto "Glória a Deus nas alturas" repetido três vezes; e o segundo, retornando à tônica (c. 11-16). Harmonicamente, a peça é totalmente diatônica, estando as notas e acordes estranhos à tonalidade apenas restritos a eventuais dominantes individuais. O contraponto utilizado por Nepomuceno é estritamente tonal, de modo geral com alternância entre $1^{\mathrm{a}}$ e $2^{\mathrm{a}}$ espécie, com amplo predomínio de sonoridades consonantes e restringindo dissonâncias a acordes de passagem ou a figurações contrapontísticas nos dois pontos cadenciais da peça (Fig. 6). 


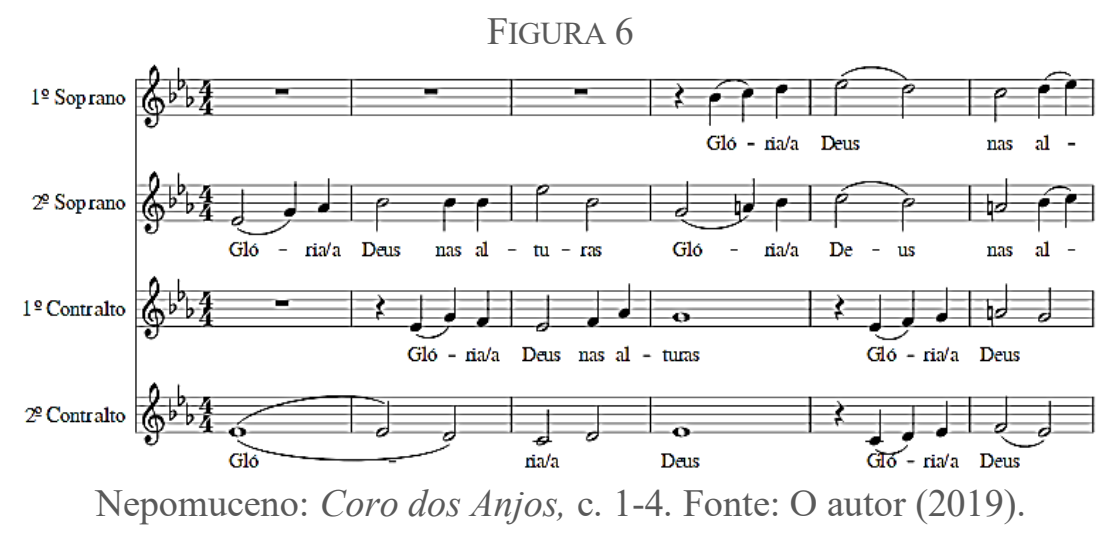

O fato de Nepomuceno optar nesta peça coral pelo uso exclusivo de vozes agudas, femininas, a cappella, e em uma escrita contrapontística se justifica pelo caráter representativo que certamente pretendia dar à obra. Com efeito, o compositor se insere, assim, numa tradição musical já consolidada de se representar musicalmente personagens espirituais, dentro de um oratório, por meio de procedimentos compositivos que remetam o ouvinte à polifonia clássica contrapontística. ${ }^{14}$ Particularmente o texto aqui empregado por Nepomuceno, o Glória a Deus nas alturas, é comumente musicado por meio de polifonia para vozes agudas e, por vezes, com orquestração que favoreça o caráter sublime de tal passagem musical. Tal procedimento pode ser encontrado também no oratório de Natal de Lorenzo Perosi. ${ }^{15}$

Em "Il Natale del Redentore", há um número exclusivamente orquestral específico ao momento em que os anjos anunciam aos pastores o nascimento de Cristo. Durante tal peça, denominada Notte tenebrosa, Perosi também recorre aos instrumentos significantes, por meio aqui de um solo de oboé, em fugato, seguido por linhas do flautim e do corne inglês (Fig. 7). Além disso, Perosi dá a seu Inno Angelico tratamento vocal semelhante ao empregado por Nepomuceno: coro feminino a quatro vozes ( 2 sopranos e 2 contraltos).

\footnotetext{
${ }^{14} \mathrm{Na}$ Sagrada Escritura lê-se que no Céu ouvem-se os cânticos dos anjos (Sl. 83, 51) e os teóricos medievais, em suas classificações dos diferentes tipos de música (entendida no sentido amplo de proporção ou ordem), reservavam uma categoria à chamada "musica celeste", que seria o resultado da ordem sábia e proporcionada na hierarquia dos Anjos e Santos. Na teoria musical medieval, após o advento técnico da polifonia musical, também se tornou comum estabelecer uma proximidade entre o efeito próprio do contraponto entre as vozes e o cântico celestial dos Anjos. Escoto Erígena, irlandês do século IX, por exemplo, "para sugerir a inexprimível beleza do Universo, não encontra imagem mais sugestiva que a de um concerto polifônico" (BRUYNE, 1994, p. 239, tradução nossa).

${ }^{15}$ O Oratório "Il Natale del Redentore" data de 1899 e divide-se em dois atos, o primeiro tratando da Anunciação e o segundo, do Natal propriamente dito. Estruturalmente, os oratórios de Perosi seguem certas tendências do tempo: são contínuos, sem números fechados seguidos por pausas, e são unificados por motivos recorrentes. O estilo melódico é predominantemente lírico tanto na escrita vocal como coral, com equilíbrio entre recitativos e ariosos, texturas predominantemente homofônicas, uso ocasional de passagens imitativas e fugatas, estilo harmônico eclético, citações historicistas (canto gregoriano, polifonia e falsebordone renascentistas) e papel proeminente da orquestra (SMITHER, 2000, p. 623).
} 
A textura é totalmente homofônica e a declamação do texto é silábica. O compositor italiano opta, contudo, por uma ampla orquestração no sentido de, como já mencionado, reforçar o caráter sublime de tal passagem, o que se dá sobretudo pelo trilo das cordas, pelo timbre da harpa e pelas figurações melódicas do flautim entre as frases corais (Fig. $8)$.

FIGURA 7
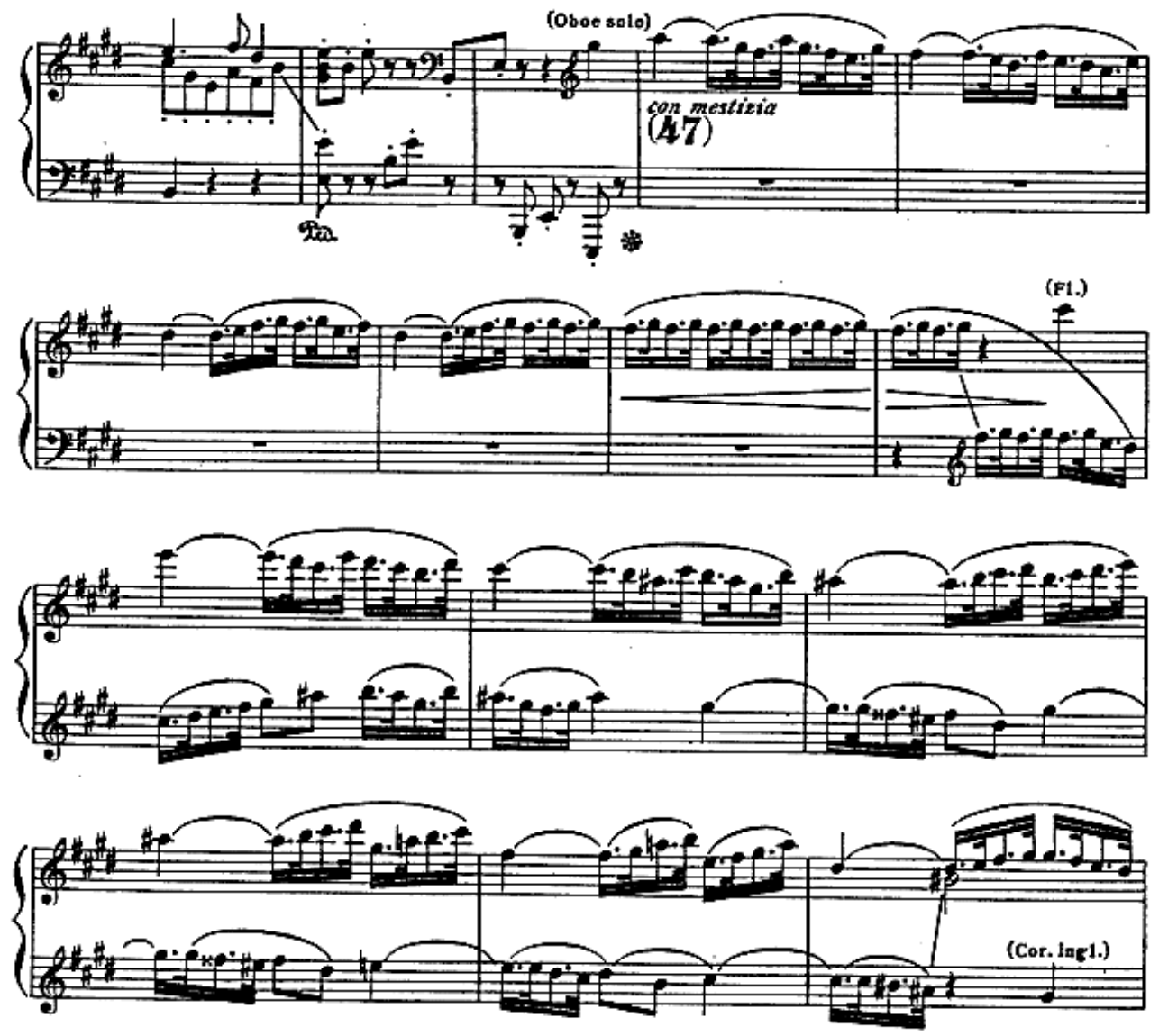

Perosi: Notte tenebrosa do oratório Il Natale del Redentore. Fonte: PEROSI (1899). 

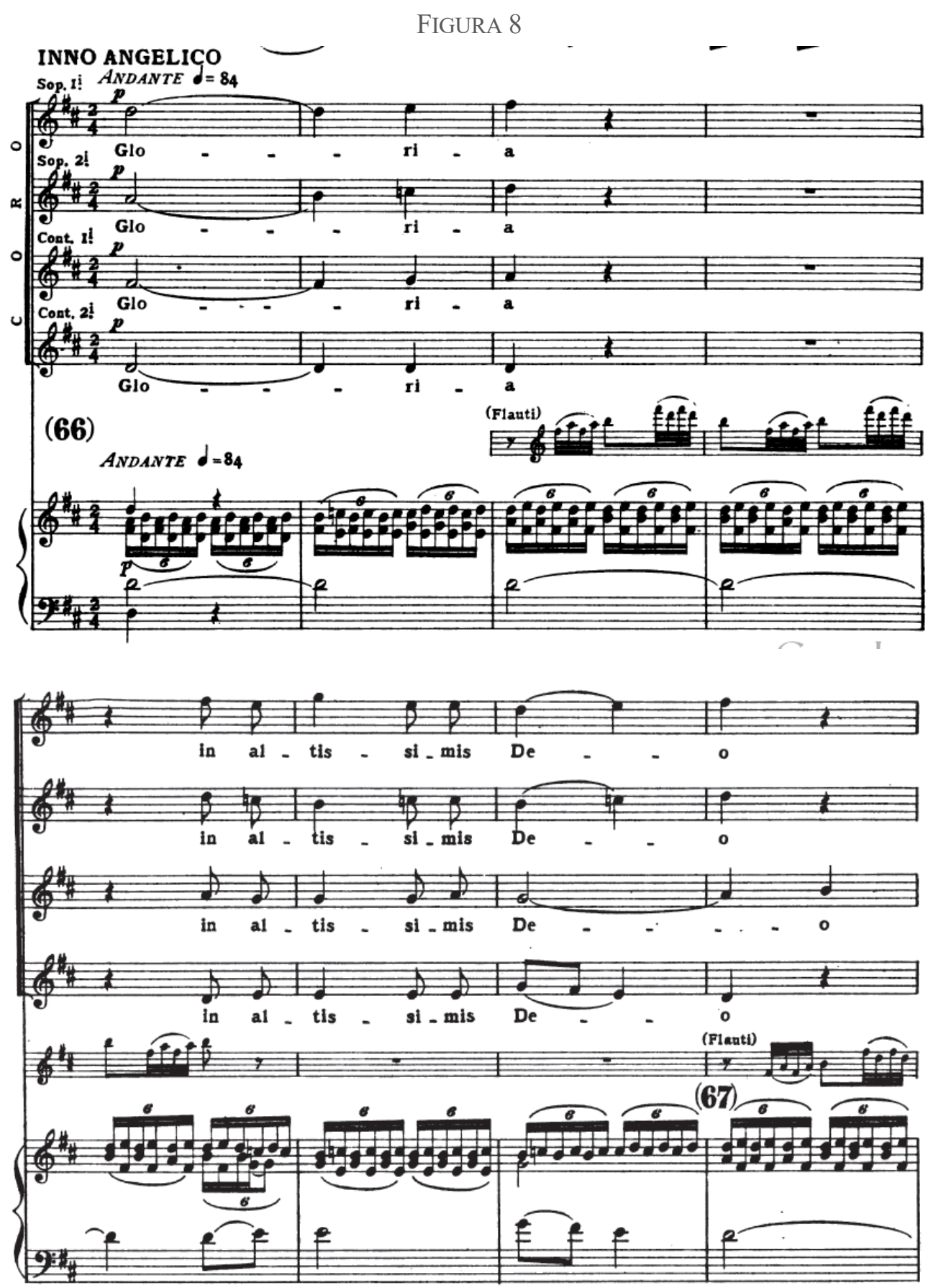

Perosi: Inno Angelico do oratório Il Natale del Redentore. Fonte: PEROSI (1899).

\section{Intertextualidade na Missa}

Entre as composições sacras e religiosas de Alberto Nepomuceno, nota-se que há apenas uma Missa, cuja edição, pela Bevilacqua \& C., apresenta o seguinte título: "Missa duabus vocibus aequalibus quam in honorem Virginis Immaculatae concinnavit et Eminentissimo Domino Cardinali Arcoverde dicavit. Die 26 Octobris Anni 1915. A. Nepomucenus" [Missa a duas vozes iguais composta em honra da Virgem Imaculada e dedicada ao Sr. Eminentíssimo Cardeal Arcoverde. Dia 26 de outubro de 1915. A. 
Nepomuceno]. A referida data de 26 de outubro de 1915 marcou o jubileu episcopal, isto é, o aniversário de vinte e cinco anos da sagração episcopal, de Dom Joaquim Arcoverde, então arcebispo do Rio de Janeiro e primeiro dos prelados sul-americanos a se tornar cardeal. Na sobredita data, o próprio cardeal celebrou uma solene missa pontifical na Catedral Metropolitana do Rio de Janeiro, com a assistência de bispos e arcebispos de todo o Brasil, sendo executada, então, a Missa que Nepomuceno dedicou-lhe. Digno de nota é o fato de que a Missa de Nepomuceno foi executada pela já mencionada Schola Cantorum Santa Cecília, conduzida pelo Pe. José Alpheu Lopes de Araújo.

A Missa de Nepomuceno segue um modelo bastante comum dentro do repertório produzido pelos compositores ligados ao Cecilianismo ${ }^{16}$ (cf. DUARTE, 2016, p. 215). Trata-se de uma composição destinada a coro a duas vozes iguais com acompanhamento de órgão. Não há árias para cantores solistas, ficando os solos vocais restritos a pequenas frases musicais intercalando os trechos corais, o que se harmoniza com as diretrizes dos documentos eclesiásticos da época, que visavam eliminar o caráter teatral na música de igreja. Predomina, pois, a escrita coral e a alternância entre texturas (imitativa/homofônica), andamentos e fórmulas de compasso como maneira de inserir variedade dentro de uma concepção geral em que a forma musical é determinada primordialmente pela estrutura do texto litúrgico. Preza-se igualmente pela inteligibilidade do mesmo texto e pela referência a modelos musicais do passado, sobretudo o cantochão e a polifonia de Palestrina (1525-1594).

Os esquemas formais utilizados em cada peça que compõe o Ordinário da Missa são compartilhados pelos compositores que de alguma forma estiveram ligados ao Cecilianismo. Em seu célebre tratado de forma musical, editado entre 1920-22, Giulio Bas (1874-1929), que atuou também diretamente no processo de restauração da música litúrgica católica no início do século XX, detalha os procedimentos formais próprios da Missa católica. No Kyrie, por exemplo, a música moderna (pós-renascentista), segundo ele, mantém a tradicional divisão A-B-A ou A-B-C, mas a distinção das partes não se

\footnotetext{
${ }^{16}$ Trata-se de um movimento artístico que tem como um de seus princípios fundamentais a ideia de que a autêntica música sacra católica é subordinada à liturgia e, portanto, a inteligibilidade das palavras e da música são mais importantes do que a individualidade artística ou que o alinhamento ao desenvolvimento contemporâneo da música em geral. O nome do movimento deve-se à Santa Cecília, Padroeira dos músicos, e às antigas Congregazioni Ceciliani do século XV, as quais vieram a inspirar a formação das chamadas Caecilien-Bündnisse (Ligas Cecilianas) em Munique, Passau, Viena e outros locais ao longo do século XVIII. Basicamente, essas organizações de músicos encorajavam a música sacra com pouco ou nenhum acompanhamento instrumental e o predomínio da música coral. É clara a ruptura entre a tendência historicista inerente ao movimento e a prática musical de então, predominantemente de caráter sinfônico, teatral e centrada sobre o gênio musical individual (cf. FELLERER, 1979, p.181; GMEINWIESER, 2001).
} 
fundamenta simplesmente na caracterização temática, mas sim em relações tonais. $\mathrm{O}$ Christe geralmente assume um caráter contrastante em relação ao primeiro e ao último Kyrie, seja no caráter, seja na tonalidade ou ainda na alternância de texturas (solo/coro, polifonia/homofonia etc.) (BAS, 1957, p. 148).

Para o Gloria, por sua vez, Bas apresenta a divisão dos versículos em quatro grupos distintos. A primeira (A), do início até Glorificamus te; a segunda (B), de Gratias agimus até Filius Patris; a terceira (C), de Qui tollis peccata mundi até Qui sedes ad dexteram Patris; e a quarta (A'), enfim, a partir de Quoniam tu solus sanctus até o final (BAS, 1957, p. 149). Na parte A distinguem-se duas partes: um período fechado, evidentemente tonal, e uma segunda como um período modulante. A parte B compõe-se por quatro períodos musicais de caráter contrastante, enquanto a parte $\mathrm{C}$ sugere três períodos musicais dispostos de forma orgânica. A parte final, com texto de caráter conclusivo, divide-se em dois períodos, geralmente o primeiro de caráter modulante e o segundo, temático e tonal (BAS, 1957, p.149-150).

No que concerne ao Credo, que, quanto à extensão do texto assemelha-se ao Gloria, Bas indica uma tríplice divisão em grandes partes, cada uma das quais inicia-se com um versículo característico, na tonalidade principal, cada parte compreendendo 5 versículos, agrupados 2+3 e 3+2. (BAS, 1957, p. 146). Para o Sanctus-Benedictus, a constituição do texto já claramente impõe a forma de Responsório, ou seja, o modelo a-b-a': após uma primeira parte (chamada corpo do responsório), sucede outra (o versículo) e, em seguida, retorna-se à primeira parte, que não é repetida inteiramente, sendo executada somente sua última frase (a frase de repetição) (BAS, op. cit., p. 129-133). O Agnus Dei, enfim, possui estreita afinidade de significado com o Kyrie, o que, segundo Bas, sugere frequentemente uma repetição ou adaptação da forma empregada no Kyrie, ou, ao menos, um desenvolvimento sobre os mesmos temas (BAS, op. cit., p. 153).

A análise musical da forma empregada por Nepomuceno em sua Missa indica uma clara adequação a estes modelos formais, o mesmo ocorrendo, de modo geral, nas várias Missas compostas por Perosi. Contudo, o modo concreto como o compositor brasileiro opta por trabalhar as articulações das texturas musicais aliado a outras características, tais como a função estrutural conferida ao tema instrumental introdutório e inclusive algumas citações temáticas diretas, permitem afirmar que Nepomuceno utiliza como modelo para sua composição a Missa Te Deum laudamus (1899) de Lorenzo Perosi, também para duas 
vozes e órgão, a qual, como já mencionado, era uma das obras do compositor italiano já conhecidas e executadas em cerimônias católicas no Brasil.

Em primeiro lugar, Nepomuceno elabora uma introdução para sua Missa com um solo de órgão com um perfil melódico que remete diretamente a padrões encontrados no repertório do canto gregoriano (Modo I - Ré-Lá-Sib-Lá) (Fig. 10). Este mesmo tema é utilizado nas demais peças da Missa, seja como prelúdio, interlúdio ou poslúdio. Tal recorrência do tema de órgão introdutório ao longo da Missa coincide exatamente com aquele empregado por Lorenzo Perosi na Missa Te Deum laudamus. (Quadro 1) e o próprio desenho melódico empregado por Nepomuceno parece remeter ao empregado por Perosi em seu moteto Ecce Panis angelorum ${ }^{17}$, de 1910 (Fig. 11). Nas Missas de Perosi também se encontra esta recorrência do tema instrumental na Missa Prima Pontificalis (1897).

FIGURA 9

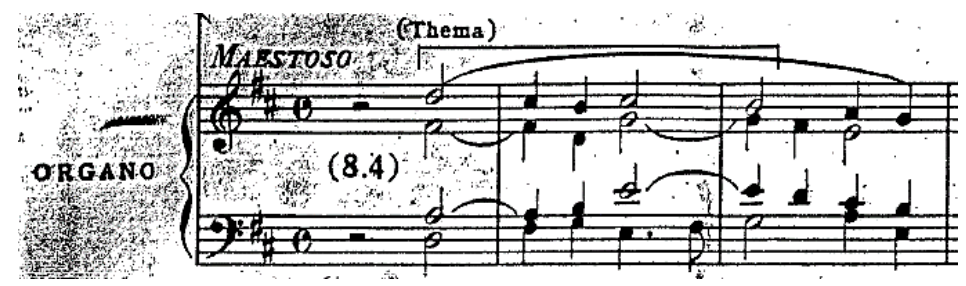

Perosi: introdução da Missa Te Deum laudamus. Fonte: PEROSI (1899).

FIGURA 10

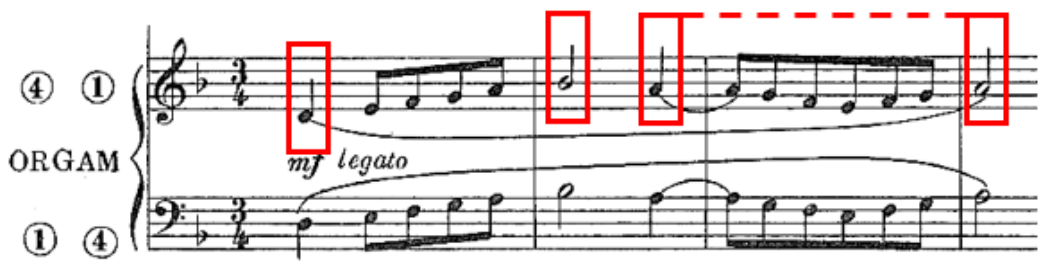

Nepomuceno: solo de órgão introdutório na Missa. Fonte: NEPOMUCENO (s.d.) [1915b].

\footnotetext{
${ }^{17}$ Nos anos em que Perosi atuou em Milão, ele compôs uma série de peças para uma ou duas vozes que foram agrupadas em quatorze volumes intitulados Melodie Sacre, publicados entre 1897 e 1910 . No volume IV, de 1900, há um moteto a duas vozes (soprano e barítono) chamado Ecce panis angelorum.
} 
QUADRO 1

\begin{tabular}{|c|c|c|c|c|}
\hline & $\begin{array}{r}\mathrm{N} \\
\mathrm{MIS} \\
\end{array}$ & $\begin{array}{l}\text { UCENO } \\
\text { UAS VOZES }\end{array}$ & MisS & $\begin{array}{l}\text { PEROSI } \\
\text { DEUM LAUDAMUS" }\end{array}$ \\
\hline \multirow{2}{*}{ KYRIE } & Introdução & c. $1-5$ & Introdução & c. $1-4$ \\
\hline & Interlúdio & c. $34-37$ & Interlúdio & c. $24-26$ \\
\hline \multirow{3}{*}{ GLORIA } & Introdução & c. $1-5$ & Introdução & c. $1-4$ \\
\hline & Interlúdio & c. $93-95$ & Interlúdio & c. $104-105$ (transposto) \\
\hline & Final & Amen (variação) & Final & Amen (variação) \\
\hline \multirow{3}{*}{ CREDO } & Introdução & c. $1-5$ & Introdução & c. $1-4$ \\
\hline & \multirow{2}{*}{ Final } & \multirow{2}{*}{ Amen } & Interlúdio & c. $164-165$ \\
\hline & & & Final & Amen \\
\hline SANCTUS & \multicolumn{2}{|l|}{-} & Introdução & c. $1-4$ (4 vozes) \\
\hline \multirow{3}{*}{ AGNUS DEI } & Introdução & c. $1-4$ & Introdução & c. $1-2$ \\
\hline & Interlúdio & c. $33-35$ & Interlúdio & c. $18-20$ (transposto) \\
\hline & Final & c. $55-58$ & Final & c. $32-34$ \\
\hline
\end{tabular}

Recorrência do tema inicial ao longo da Missa: Nepomuceno x Perosi. Fonte: O autor (2019).

\section{FIGURA 11}
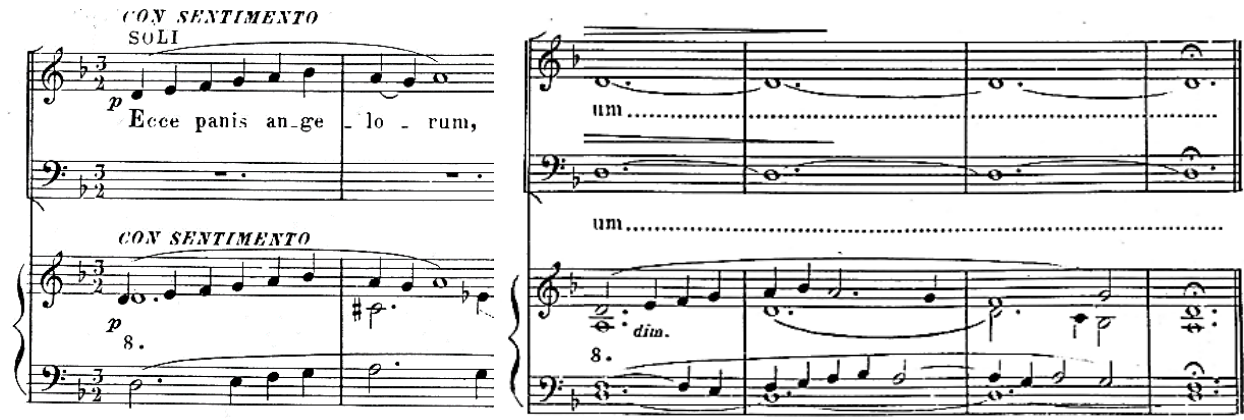

Perosi: tema inicial e final no moteto Ecce panis angelorum. Fonte: PEROSI (1899).

Realizando-se uma análise comparativa entre o Gloria de Nepomuceno, com o da Missa Te Deum laudamus de Perosi observa-se que há dois tipos de intertextualidade musical. ${ }^{18}$ Em primeiro lugar, uma citação de esquema formal. Com efeito, tanto o Gloria de Nepomuceno como o de Perosi iniciam-se com o mesmo tema introdutório com solo de órgão utilizado nos respectivos Kyries; há alternância de andamentos e de fórmulas de compasso da mesma maneira em ambas as peças, corroborando a mesma divisão formal; e, enfim, os pontos em que ocorrem mudanças na textura musical, seja de tutti para solo ou de homofonia para imitação, são praticamente os mesmos em ambos os Glorias. O

\footnotetext{
${ }^{18}$ Como ferramenta para a específica abordagem de relações de intertextualidade musical, utilizaremos a sistematização proposta por Corrado (1992, p. 34), que, na área por ele chamada de intrassemiótica, a qual contém os fatos produzidos com meios estritamente musicais, distingue três tipos de citação musical: (1) "Citação de materiais geradores" ou de esquemas formais (ex: missas ou motetos medievais construídos a partir de um cantus firmus); (2) "Citação estilística", falsa citação ou citação sintética: reconstituição de gestos formais e expressivos dominantes de um estilo, mas sem referência a uma obra em particular, com diferentes graus de fidelidade (ex: paródia estilística, pastiche, neoclassicismo do início do século XX etc.); e (3) "Citação textual": incorporação de materiais temáticos reconhecíveis (melodias ou complexos polifônicos) tomados de uma determinada obra preexistente, podendo ser uma "autocitação", uma "transcrição criativa", um "empréstimo temático ou uma "citação com intenção referencial" (CORRADO, 1992, p. 34-40).
} 
segundo tipo de intertextualidade corresponde a uma apropriação de elemento temático. Trata-se do trecho Domine Deus, agnus Dei, Filius Patris (Fig. 12 e 13). Nepomuceno dá música a este versículo através de uma estrutura fraseológica binária, sendo a primeira de escrita claramente imitativa a partir do motivo Lá-Ré (com ritmo semínima pontuadacolcheia-semínima-semínima) na Voz 1 e a imediata repetição/resposta na Voz 2 em Domine Deus. Em seguida, em Agnus Dei, c. 60, escreve novamente uma frase de caráter contrapontístico, ainda que não imitativo, e, finalmente, encerra com Filius Patris em estrito uníssono das duas vozes. Harmonicamente, tem-se o trecho iniciando-se em Ré menor, tonicização na relativa maior, Fá maior e encerramento na dominante, Lá maior.

Perosi, por sua vez, faz procedimento quase idêntico. Em primeiro lugar, tem-se o mesmo motivo melódico ( $4^{\mathrm{a}}$ ascendente) Si-Mi (com ritmo semínima-colcheia-colcheiamínima) como pergunta/resposta entre as duas vozes em Domine Deus, c. 42. Em segundo lugar, no c. 44, o Agnus Dei inicia-se com as vozes defasadas e, finalmente, no c. 49 o Filius Patris é em estrito uníssono. Harmonicamente, tem-se neste trecho uma clara afirmação da tônica, Si menor, tanto em Domine Deus (relação IV-I) como em Agnus Dei (V-I), e em Filius Patris um encaminhamento à dominante, Fá\# maior. A conclusão de ambas as frases em Filius Patris uníssono também apresenta certa semelhança de constituição melódica, pois ambos os compositores optam por uma linha melódica de perfil quase simétrico, com ascensão em Filius, ponto culminante em Patris e cadenciamento em linha descendente, configurando-se uma mesma concepção na relação melodia/texto.

\section{FIGURA 12}

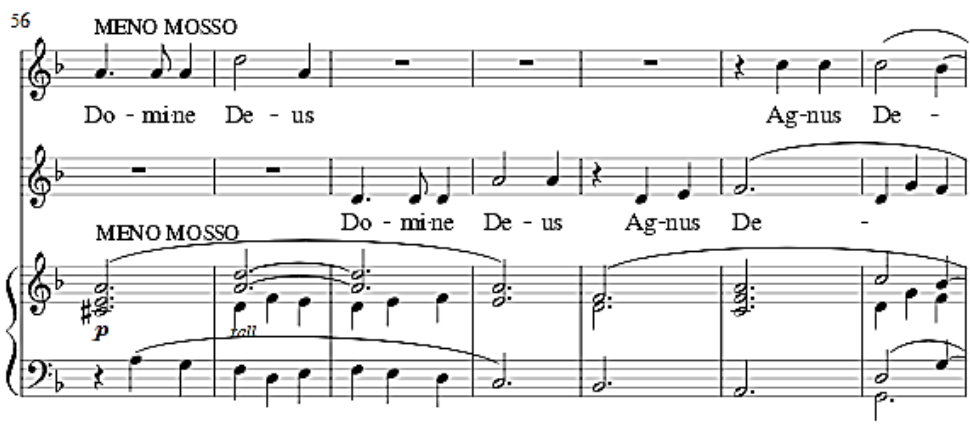




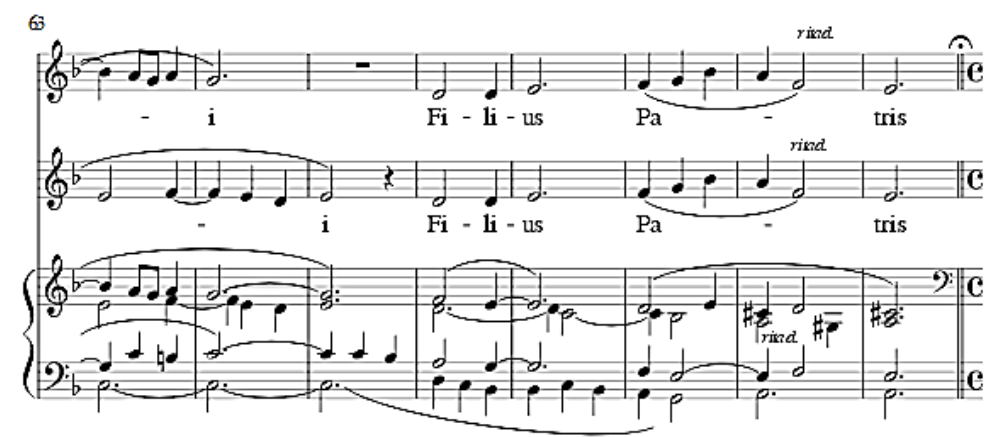

Nepomuceno: Gloria da Missa, c. 56-70. Fonte: O autor (2019).

FIGURA 13
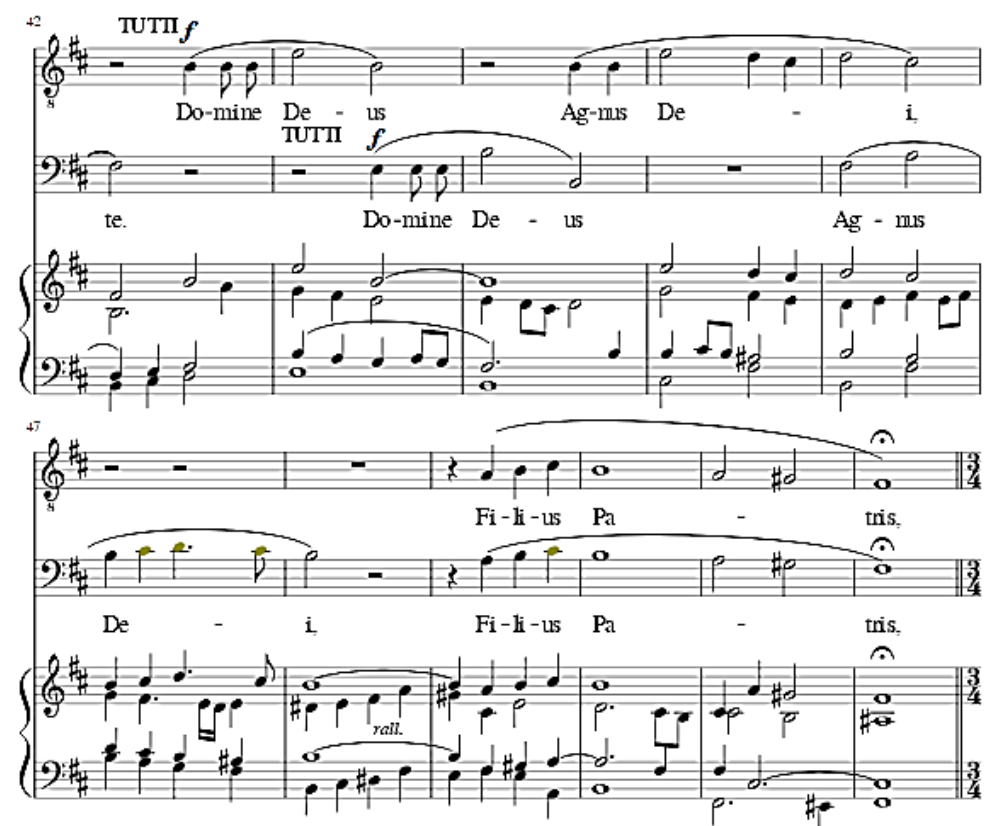

Perosi: Gloria da Missa Te Deum laudamus, c. 42-52. Fonte: PEROSI (1899).

Também no Credo de Nepomuceno verifica-se uma citação de esquema formal do Credo da já citada Missa de Perosi. Em primeiro lugar, pelo duplo uso da introdução com solo de órgão. Em segundo lugar, ambos os Credo apresentam a tríplice divisão formal proposta por Bas para tal peça da Missa. Em terceiro lugar, enfim, as alterações na métrica ocorrem exatamente no mesmo ponto estrutural de ambos os Credo. No Credo de Perosi, as fórmulas de compasso são: 1) 4/4 até descendit de coelis, c. 49;2) 3/4 até ad dexteram Patris, c. 112; e 3) 4/4 até o final. No Credo de Nepomuceno, as fórmulas de compasso são: 3/4 até descendit de coelis, compasso 78; 2) 4/4 até ad dexteram Patris, c. 141; e 3) $3 / 4$ até o final.

A maior proximidade entre a Missa de Nepomuceno e a Missa Te Deum laudamus de Perosi se dá, entretanto, no Sanctus. De fato, quanto à estrutura geral, no que concerne à divisão dos diversos períodos do texto litúrgico entre as vozes e à respectiva textura 
coral empregada, verifica-se que as duas peças podem ser consideradas praticamente idênticas, valendo-se ambos os compositores da forma de Responsório, fundamentando a distinção das partes na maior ou menor orquestração vocal e no emprego de texturas homofônicas e imitativas (Quadro 2).

QUADRO 2

\begin{tabular}{|c|c|c|}
\hline & $\begin{array}{c}\text { NEPOMUCENO } \\
\text { MISSA A DUAS VOZES }\end{array}$ & $\begin{array}{c}\text { PEROSI } \\
\text { MISSA “TE DEUM LAUDAMUS" }\end{array}$ \\
\hline & \multicolumn{2}{|c|}{ SANCTUS } \\
\hline Introdução & Órgão solo & Órgão solo \\
\hline Sanctus, Sanctus, & Voz 1 solo & Voz 1 solo \\
\hline $\begin{array}{l}\text { Sanctus, Dominus Deus } \\
\text { Sabaoth }\end{array}$ & Voz 2 solo & Voz 2 solo \\
\hline Pleni sunt caeli et terra & Voz 1 e 2 - Textura homofônica & Voz 1 e $2-$ Textura homofônica \\
\hline gloria tua & Voz 1 e 2 - Textura imitativa & Voz 1 e $2-$ Textura imitativa \\
\hline Hosanna in excelsis & Voz 1 e 2 - Textura homofônica & Voz 1 e 2 - Textura homofônica \\
\hline
\end{tabular}

Forma geral do Sanctus da Missa de Nepomuceno e de Perosi. Fonte: O autor (2019).

Além da citação de esquema formal, o Sanctus de Nepomuceno reproduz determinados desenhos melódicos e, algumas vezes, até as mesmas relações intervalares presentes em determinados trechos da obra de Perosi, refletindo assim uma citação textual, isto é, uma incorporação de materiais reconhecíveis tomados de outra obra preexistente. Configura-se, assim, uma paráfrase (citação reelaborada livremente), abrangendo desde a forma geral até o nível das frases musicais, por meio de citação de elementos musicais de pequena dimensão. Destacamos a grande semelhança no tema inicial, intercalado entre as duas vozes (Fig. 14 e 15); a semelhança de perfil melódico e de estruturação harmônica em Pleni sunt coeli et terra (Fig. 16 e 17); a idêntica textura imitativa em gloria tua (Fig. 18 e 19); e a estrutura fraseológica e os procedimentos cadenciais na frase final (Fig. 20 e 21). 
FIGURA 14

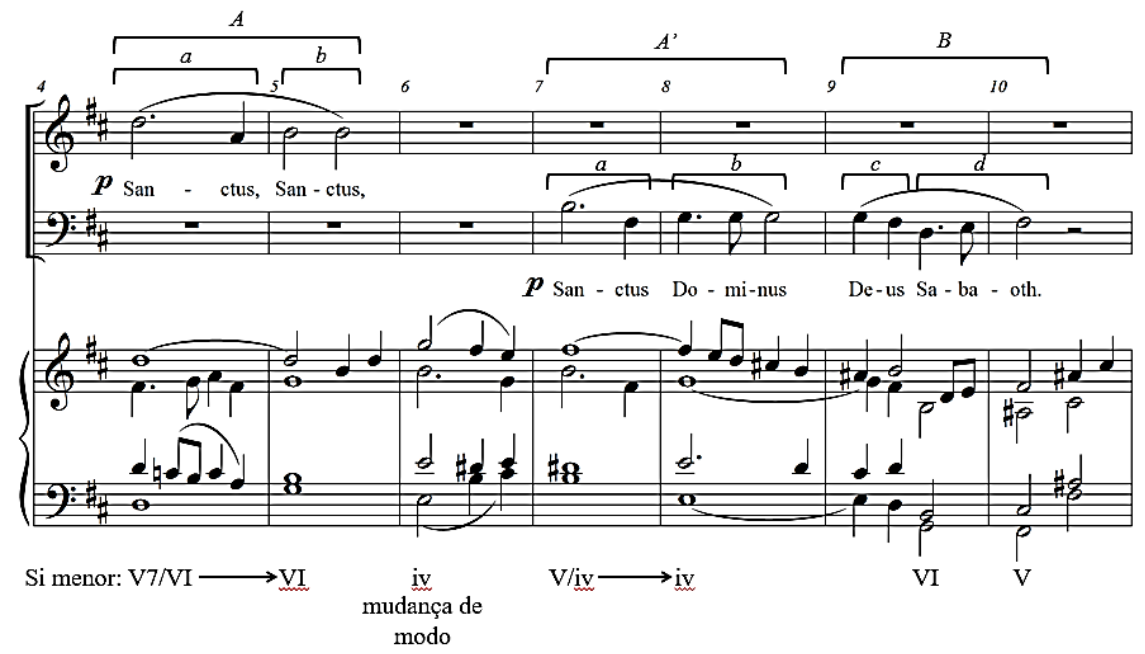

Perosi: Sanctus da Missa Te Deum laudamus, c. 4-10. Fonte: O autor (2019).

FIGURA 15

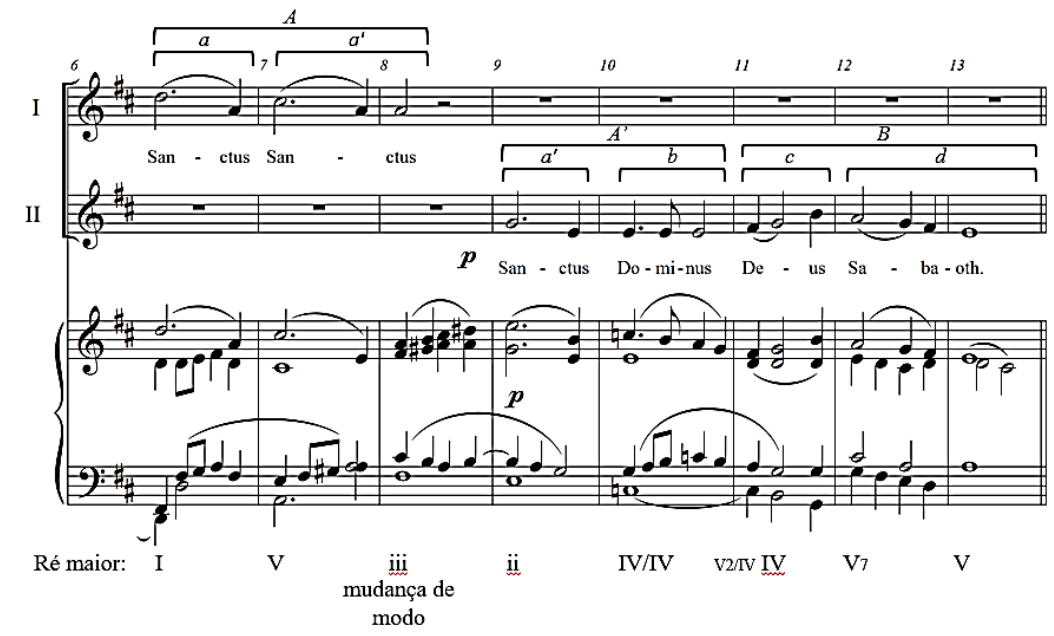

Nepomuceno: Sanctus, c. 4-13. Fonte: O autor (2019).

FIGURA 16
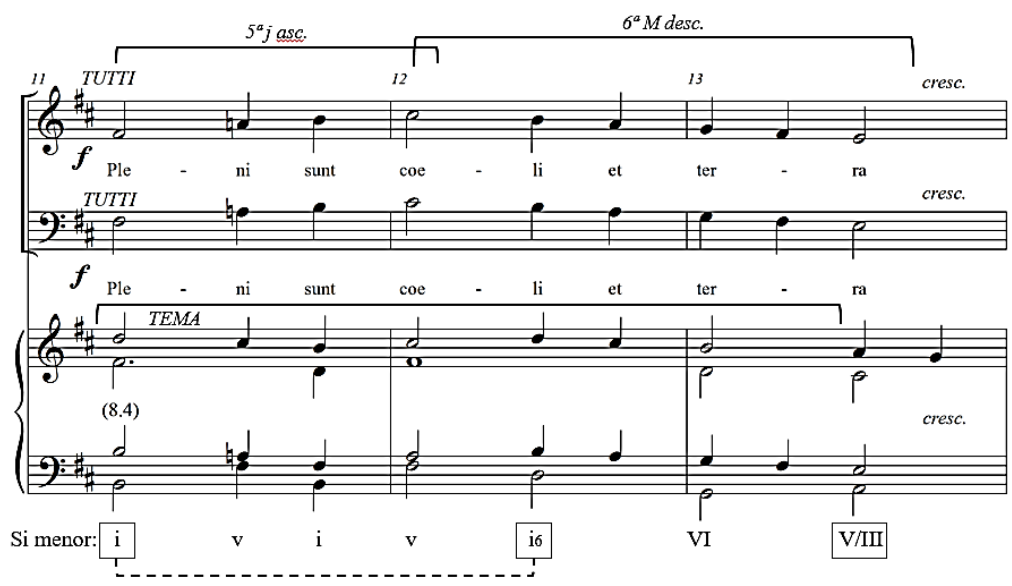

Perosi: Sanctus da Missa Te Deum laudamus, c. 11-13. Fonte: O autor (2019). 
FIGURA 17

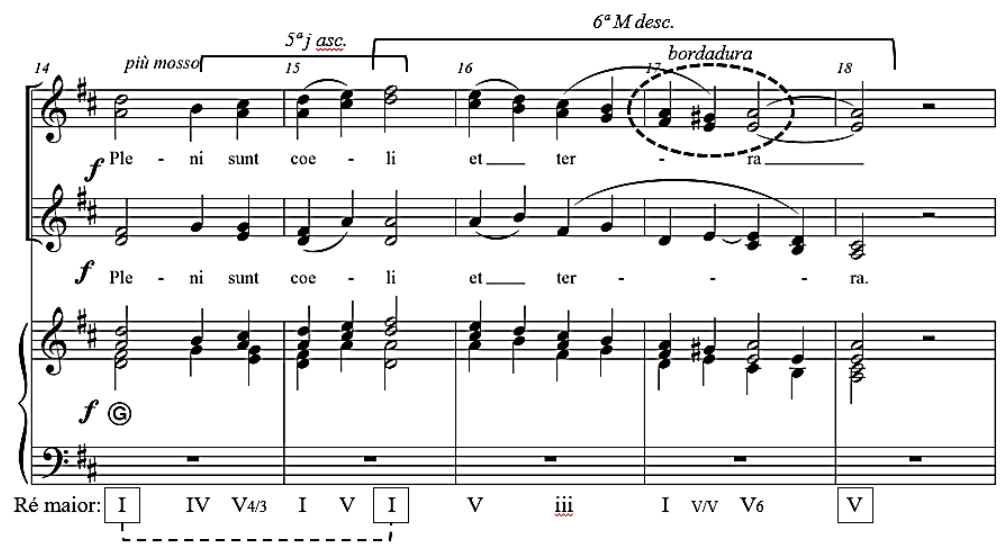

Nepomuceno: Sanctus, c. 14-18. Fonte: O autor (2019).

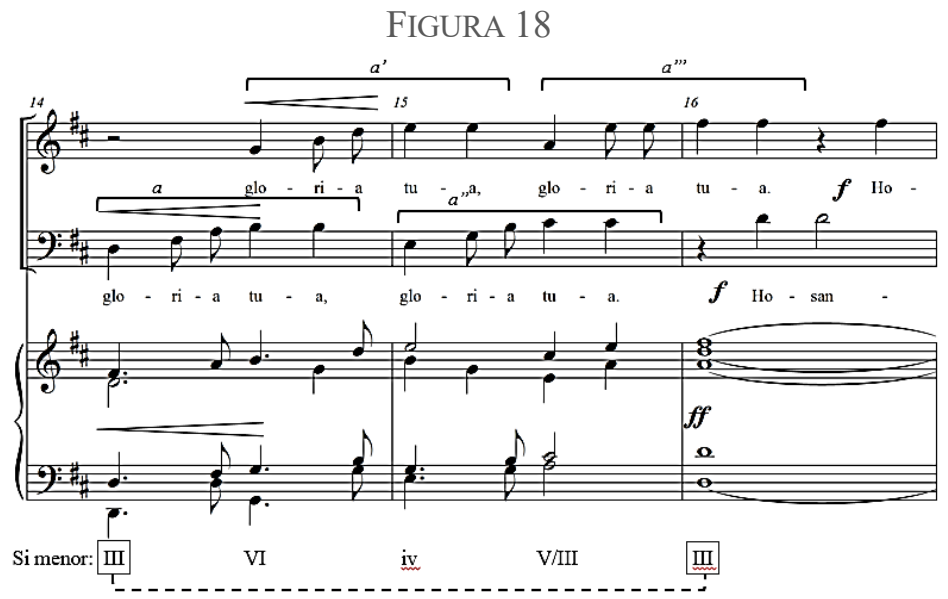

Perosi: Sanctus da Missa Te Deum laudamus, c. 14-16. Fonte: O autor (2019).

FIGURA 19

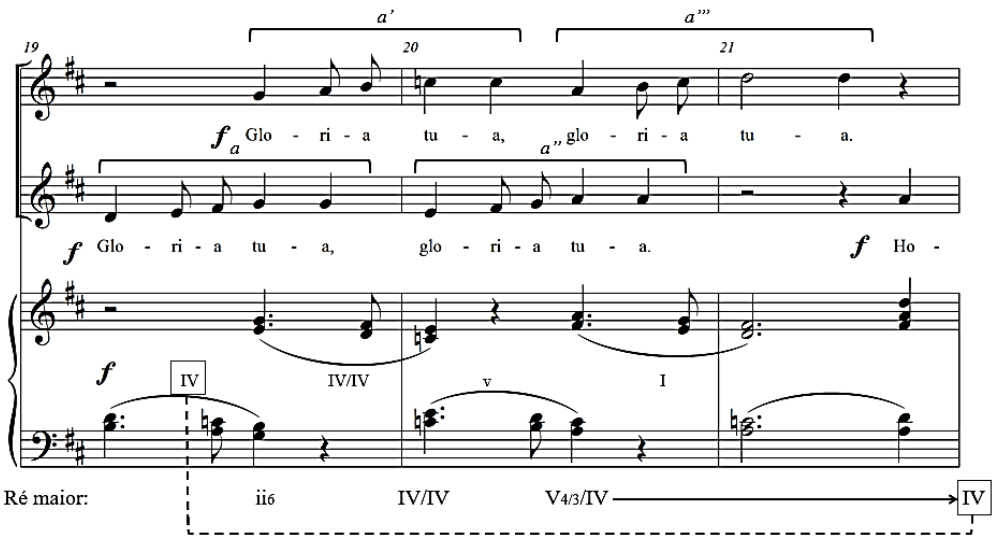

Nepomuceno: Sanctus da Missa, c. 19-21. Fonte: O autor (2019). 
FIGURA 20

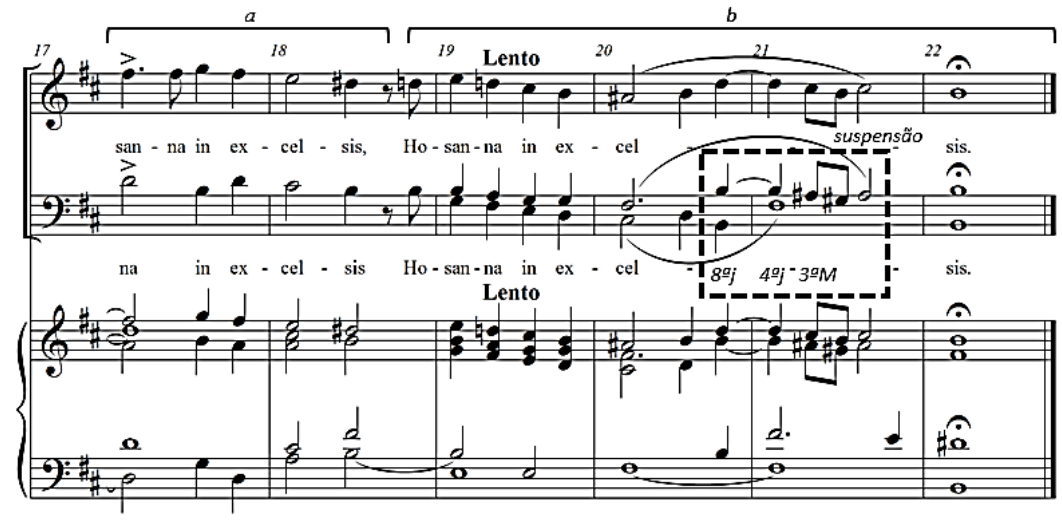

\begin{tabular}{llllll} 
Simenor: III & VI III & V/III V/iv & iv & V & I \\
\cline { 5 - 6 }$n n n n$
\end{tabular}

Perosi: Sanctus da Missa Te Deum laudamus, c. 17-22 (final). Fonte: O autor (2019).

FIGURA 21

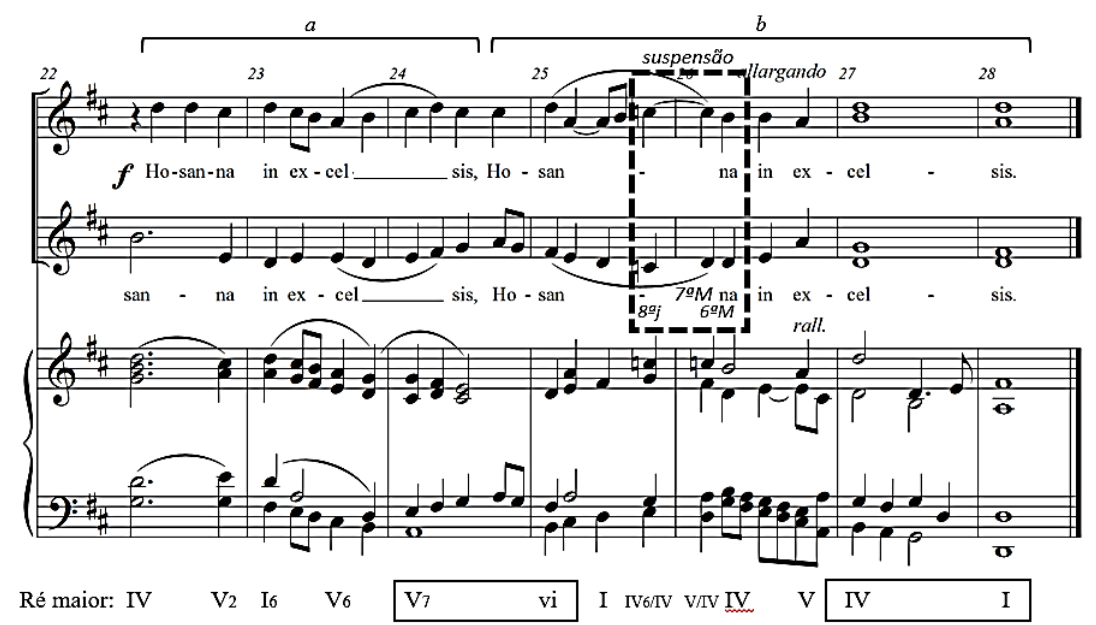

Nepomuceno: Sanctus da Missa, c. 22-28 (final). Fonte: O autor (2019).

\section{Conclusões}

Primeiramente, foi possível traçar um panorama geral da recepção da música de Lorenzo Perosi no Brasil entre o final do século XIX e o início do século XX, sobretudo no que concerne à sua música estritamente litúrgica, amplamente empregada e divulgada nos meios eclesiásticos brasileiros.

No que concerne à produção sacra e religiosa de Alberto Nepomuceno, verificaramse elementos musicais comuns com relação à música de Perosi, particularmente a valorização e o tratamento harmônico dado ao canto gregoriano e a utilização de elementos representativos e de tópicas pastoris na produção de oratório, gênero no qual Perosi tornou-se especialmente célebre em sua época. 
Finalmente, apresentaram-se alguns casos específicos de intertextualidade musical na Missa a duas vozes de Nepomuceno. Na macro-dimensão ${ }^{19}$ há, em primeiro lugar, uma citação de esquemas formais, por meio da utilização de um tema introdutório para solo de órgão como elemento recorrente em todas as peças da Missa: prelúdio e interlúdio do Kyrie; prelúdio e interlúdio do Gloria; prelúdio e Amen final do Credo; prelúdio, interlúdio e poslúdio do Agnus Dei. O mesmo procedimento sendo utilizado por Perosi em sua Missa Te Deum laudamus (1899). Em segundo lugar, há na Missa de Nepomuceno o emprego de modelos formais correspondentes, em geral, à sistematização proposta por Giulio Bas e, em particular, à utilizada por Perosi na Missa Te Deum laudamus: Kyrie com tríplice divisão A-B-C; Gloria com quádrupla divisão (A-B-C-A'); Credo com quádrupla divisão (A-B-C-Coda), cada parte compreendendo 5 versículos do texto; Sanctus-Benedictus na forma de responsório (A-B-A' e frase de repetição); e Agnus Dei com tríplice divisão (A-A-B).

Na média-dimensão, apresentaram-se citações textuais, com empréstimo temático. Em primeiro lugar, um tema introdutório para solo de órgão com perfil melódico e função formal semelhantes ao moteto Ecce panis angelorum, de Perosi. Em segundo lugar, o trecho Domine Deus, agnus Dei, Filius Patris do Gloria semelhante, em termos de motivo melódico, de harmonia, de texto e de textura, ao mesmo trecho da Missa Te Deum laudamus de Perosi. Em terceiro lugar, enfim, toda a peça Sanctus corresponde, em termos formais e temáticos, ao Sanctus da Missa Te Deum laudamus de Perosi.

Assim, procuramos apresentar uma primeira contribuição a um aspecto ainda pouco explorado da musicologia brasileira, a saber, a recepção e a influência da música de Lorenzo Perosi na produção de música sacra dos compositores brasileiros do século XX.

\section{Referências}

BAS, Giulio. Tratado de la forma musical. 3. ed. Buenos Aires, Ricordi, [1920-1922] 1957.

BRUYNE, Edgar De. La estética de la Edad Media. Madrid: Visor, 1994.

CIAMPA, Leonardo. Don Lorenzo Perosi. Bloomington: AuthorHouse, 2006.

\footnotetext{
${ }^{19}$ Consideramos aqui as categorias de intertextualidade musical aplicáveis a três níveis distintos da obra musical, as chamadas dimensões principais da análise segundo LaRue: 1) grande, 2) média e 3) pequena (LARUE, 1989, p. 3-5). De modo análogo, também White propõe uma distinção dos níveis de uma peça musical para fins de análise, igualmente dirigida para os quatro parâmetros (ritmo, melodia, harmonia e som): a microanálise em nível motívico; a média-análise em nível de frases e estruturas semelhantes; e a macro análise, no nível mais amplo das obras (WHITE, 1994, p. 25-27).
} 
CORRADO, Omar. Posibilidades intertextuales del dispositivo musical. In: CORRADO, O; KREICHMAN, R.; MALACHEVSKY, J. (eds.). Migraciones de sentidos: tres enfoques sobre lo intertextual. Santa Fe: Universidad Nacional del Litoral, Centro de Publicaciones, 1992. p. 3351.

CORRÊA, Sérgio Alvim. Alberto Nepomuceno; catálogo geral. 2. ed. Rio de Janeiro: Funarte/Coordenação de Música, 1996.

CORREIO DA MANHÃ, Rio de Janeiro, 10/08/1906.

Documentos sobre a música litúrgica. São Paulo: Paulus, 2005

DUARTE, Fernando Lacerda S. Resgates e abandonos do passado na prática musical litúrgica católica no brasil entre os pontificados de Pio Xe Bento XVI (1903-2013). 496f. Tese (Doutorado em Música) - Instituto de Artes da Universidade Estadual Paulista "Júlio de Mesquita Filho", Unesp, São Paulo, 2016.

FELLERER, Karl Gustav. The History of Catholic Church Music. Westport: Greenwood Press, 1979.

GMEINWIESER, S. CECILIAN MOVEMENT. In: The New Grove Dictionary of Music and Musicians. London: Macmillan, 2001. Disponível em: $<$ http://www.oxfordmusiconline.com/subscriber/article/grove/music/05245? q=cecilianism\&sear $\mathrm{ch}=$ quick\&source $=$ omo_gmo\&pos=7\&_start=1\#firsthit $>$ Acesso em: 07/01/2017.

GOLDBERG, Luiz Guilherme. Alberto Nepomuceno e a Missa de Santa Cecília. In: ENCONTRO DE MUSICOLOGIA HISTÓRICA, 6, 2006, Juiz de Fora. Anais... Juiz de Fora, 2006a, p. 146-172.

JORNAL DO BRASIL, Rio de Janeiro, 16/07/1958.

JORNAL DO BRASIL, Rio de Janeiro, 31/08/1904.

JORNAL DO COMMERCIO, Rio de Janeiro, 25/12/1898, Theatros e Musica, p. 5.

, Rio de Janeiro, 03/03/1899, Theatros e Música, p. 2.

, Rio de Janeiro, 11/07/1910, Notícias religiosas, p. 4.

, Rio de Janeiro, 04/07/1914a, p. 12.

, Rio de Janeiro, 30/08/1914b, Gazetilha, p. 4.

, Rio de Janeiro, 22/11/1915. Notícias religiosas, p. 4.

, Rio de Janeiro, 01/07/1916a, p. 16.

, Rio de Janeiro, 30/10/1916b, Notícias religiosas, p. 4.

, Rio de Janeiro, 06/12/1916c, Notícias religiosas, p. 3.

LARUE, Jan. Análisis del estilo musical: pautas sobre la contribución a la música del sonido, la armonía, la melodía, el ritmo y el crecimiento formal. Barcelona: Labor, 1989.

MONELLE, Raymond. Musical Topic: Hunt, Military and Pastoral. Bloomington: Indiana University Press, 2006. 
NEPOMUCENO, Alberto. Cloches de Noël. Rio de Janeiro: Sampaio Araújo \& Cia., [1915a]. Partitura (5 p). Piano.

. Em Bethleem. Fundação Biblioteca Nacional - Divisão de Música e Arquivo Sonoro, M785.1. [1903] Partitura manuscrita (48p.). Canto, Coro e Orquestra.

NIEDERMEYER, Louis; D'ORTIGUE, Joseph. Gregorian Accompaniment: A Theoretical and Practical Treatise upon the Accompaniment of Plainsong. London: Novello, Ewer \& Co., 1905.

PEROSI, L. Il Natale del Redentore. Milano: G. Ricordi \& C., [1899]. Partitura. e órgão. . Melodie sacre. Milan: Musica Sacra Bertarelli, s.d. [1900]. v. 4. Partitura (49 p.). Coro

. Missa De Beata: col proprio della Messa "Puer" secondo la lezione dei Codici, con accompagnamento ed interludi d'organo, dedicata ai Seminaristi d'Italia. Milão: A. Bertarelli, [s.d.]. 1 Partitura (29 p.). Órgão. vozes e Órgão.

Missa Te Deum laudamus. Milão: Ricordi, 1899. 1 Partitura (17 p.). Coro misto a 2

SCHUBERT, Guilherme. Música Sacra no Rio de Janeiro em redor de 1910. In: Brasil 19001910. Rio de Janeiro: Biblioteca Nacional, 1980. p.11-45.

SMITHER, H. E. A History of the Oratorio. Chapel Hill: The University of North Carolina Press, 2000. v.4: The Oratorio in the Nineteenth and Twentieth Centuries.

TEIXEIRA, Thiago Plaça. A música sacra e religiosa de Alberto Nepomuceno (1864-1920): estilo e intertextualidade. 445f. Tese (Doutorado em Música) - Setor de Artes, Comunicação e Design, Universidade Federal do Paraná, Curitiba, 2019.

WATERHOUSE, John C. G. PEROSI, LORENZO. In: The New Grove Dictionary of Music and Musicians. London: Macmillan, 2001. Disponível em: $<$ http://www.oxfordmusiconline.com/grovemusic/view/10.1093/gmo/9781561592630.001.0001 /omo-9781561592630-e-0000021357?rskey=v2KpsH\&result=1>. Acesso em: 29/04/2019.

WHITE, John D. Comprehensive Musical Analysis. London: Scarecrow Press, Inc., 1994. 